UDC 811.11'42

DOI https://doi.org/10.32841/2409-1154.2020.46-1.17 Havryliuk O. O.,
Candidate of Philological Sciences,
Assistant Professor at the Department of English Philology and Intercultural Communication
Taras Shevchenko National University of Kyiv

Nikiforova Ye. Yu., Candidate of Philological Sciences, Assistant Professor at the Department of English Philology and Intercultural Communication Taras Shevchenko National University of Kyiv

\title{
VIRTUAL LANGUAGE IDENTITIES ON SOCIAL NETWORKING SITES (BASED ON FACEBOOK COMMENTARIES)
}

\begin{abstract}
Summary. In this paper, we examine different types of virtual language identities communicating on social networking sites, Facebook in particular. Basing our discussion on Facebook commentaries, we present profiles of Facebook users whose commentaries have certain language features and communicative goals. The findings reveal that not every speaker can be called a virtual language identity as they may not use language means for their self-representation on social networking websites (such users as a lurker, window shopper, selfie, spammer). Also, we outlined and examined the following types of Facebook users: moderator, troll or hater, expert, off-topic speaker, narrator, adviser. These personalities can be called virtual language identities as they produce text (Facebook commentary) intending to cultivate self-image, they have their own communicative goals and verbal means specific to their commentaries Moderators communicate on Facebook to enforce rules and sometimes facilitate discussion but mainly this function of moderators has been lost in social networking websites. Virtual language identity troll (hater) tries to involve other Facebook users into conflict or heated discussion, their aim may also be to abuse other members of community. Off-topic speaker's main goal is to make discussion confused and cumbersome in every possible way. The communicative goal of an expert is to provide information whereas a narrator uses language means to assert oneself. Adviser's communicative goal is to consult and help other users in solving their issues. In the paper, the complex linguistic analysis of the Facebook commentaries of these identities was carried out. The results of the study show that each virtual language identity uses their own verbal means to achieve their goal: trolls or haters use abusive language, experts' commentaries are well-structured and usually quite long and sometimes cumbersome, a narrator uses techniques peculiar to story-telling and advisers' comments are full of sentences with imperative mood and appeal to authority or speaker's personal experience that helps to establish rapport between community members. The article highlights the main virtual language identities but other types of users can also be found on Facebook.

Key words: social networking website, Facebook commentary, virtual language identity, communicative goal, language means.
\end{abstract}

Introduction. Undoubtedly, social networking websites have become an inseparable part of the information society. They play a significant role in mass communication as they provide the communication platform for people of different walks of life such as teenagers, office workers, politicians, housewives. Therefore, we may claim that they unite all sections of society. This is to certify that a person stands in the centre of a communicative model of the Internet. The purpose of the research is to examine Facebook commentaries and identify types of virtual language identities peculiar to it. The target of the article is the detailed investigation of verbal means of different virtual language identities (Facebook users). The scientific novelty lies in the fact that the identity construction of Facebook users has not been investigated profoundly, even though Internet communication has long been in the centre of attention of linguists. The object of the research is virtual language identities that could be found on Facebook as well as commentaries of the members of the most popular Facebook communities. The subject of the investigation is verbal means used by different virtual language identities in Facebook commentaries.

Recent research and publications. Social networking website is a platform where people can create public accounts to build social relationships with other people who share similar interest [17]. Social networking sites and their genres have been the centre of attention of the following foreign and domestic linguists: Kaptiurova V.V. (pragmatic principles of posts on social networking sites) [8], Seargeant P. and Tagg C. (social media communities) [15], danah $\mathrm{m}$. boyd and Nicole B. Ellison (definition and history of social network sites) [4], Dziubina O. (neologisms on Facebook and Twitter) [6] and others. Among the most popular social networking sites, we can find Facebook, Instagram and Twitter. Once founded in 2004 by a group of Harvard University students for interaction between them, Facebook has grown into the largest social networking website. According to recent statistics, the total number of active Facebook users is 2.70 billion people [7]. Facebook as a genre of Internet discourse has the following features: globality (international network and mass user access to it); interactivity (communication is the key concept); hypertextuality (you can post any links to any kind of information (audio, video, text)); creativity (you can construct your identity in many different ways to attract the attention of other users); continuity; technicality (Facebook developers constantly invent various technical means to make it more attractive and convenient for the users); ease of handling network data; brevity and jargon of the expression of thoughts; the difficulty of the emotional communication; the desire for emotional filling of the text (that is represented through a wide range of offered reactions to the post) $[20$, p. 78]. One of the most import- 
ant features is that Facebook is an asynchronous type of communication and it results in the fact that users still have enough time to organize their thoughts and ideas into a comprehensive text.

The main purpose of social networking sites such as Facebook is to organize community based on common interests. In fact, Facebook resembles people's diaries or journals containing biographical data, photos and other personal information. So, in the centre of Facebook, we can find a person with their own means for constructing identity. At the outset, Facebook contained profiles providing real information as the main purpose was to find someone you know. Now anonymity of the Internet overtook even social networking sites and you can find there loads of profiles of people but it remains hard to check whether the information on the page is real or fake. Moreover, a person still has additional means to create an identity they desire. Dressler \& Dressler claim that the main means for constructing identity on Facebook are mostly linguacultural and are based on the person's status updates, comments and "likes" of the posts $[5, \mathrm{p} .25]$. So, these means remain the most relevant material for analysing a person's identity on Facebook. Communication on social media is "masspersonal" that means that you are writing a post containing personal information but it is distributed to many addresses [5, p. 26]. Meanwhile, we must agree that Facebook page is extremely significant in constructing virtual identity $[19$, p. 310] but the scope of our interest is virtual language identity that is only possible to study investigating the text and in our case Facebook commentaries to other users' posts.

Virtual language identity continues to capture the attention of foreign and domestic scholars such as Nikiforova Ye.Yu. (types of forum users) [11], Asmus N. (analysed linguistic features of virtual space) [2], Kompantseva L. (analysed Internet communication and touched some aspects of virtual identities in it) [9], Lutovinova 0 . (within the frames of analysis of virtual discourse touched the issue of differentiating types of users who communicate online) [10] and others. Virtual language identity is a discursive variant of language identity who communicates in the language space of the Internet, fixed in communicative strategies and tactics, types of language behaviour, linguocognitive peculiarities of the thesaurus [11, p. 23]. Nikiforova Ye.Yu. claims that everyone who uses the Internet to satisfy their own needs can already be called virtual identity [11, p. 61]. As it can be inferred, Facebook has been widely studied but virtual language identities present on Facebook has never been in the centre of attention before.

Results and discussions. It is reasonable to start analysing virtual language identities on Facebook considering their aims, functions, motives and motivations, peculiarities of their language behavior. Virtual language identities on Facebook can be classified according to an illocutionary force of the utterance: 1) to provide information as to certain issue: consultant, informer, expert; 2 ) to assert oneself or draw attention to oneself: relationship builders, self-promoter, selfie, creator, narrator; 3) to abuse other user and to make communication complicated and provoke conflicts: troll, hater flamer, off-topic speaker, spammer; 4) to resolve conflicts, enforce the rules and facilitate communication: moderator, peace-keeper or diplomat [12, p. 194]. Actually, these types of users can be found on any communicative service of the Internet but we will make an attempt to identify types of virtual language identities you can come across on Facebook and describe their communicative goals and verbal peculiarities of their posts.
First of all, everyone who signs up and registers their page is already considered to be a virtual identity. People who usually just read status updates and comments of other people but do not contribute themselves are called lurker or window shopper [14]. They often claim that they have a social obligation to have a Facebook page but do not want to be active users [1]. So, this personality cannot be considered as language one as they rarely comment and contribute to the life of the community.

The next type of virtual language identity we want to focus on is moderator. In a forum communication, moderator is the key personality and has several functions such as enforcing the rules, controlling communication, facilitating discussion [11, p. 63]. On Facebook, moderators lost their functions and perform mainly as administrators of the Facebook community who can accept new members and moderate their posts as well as enforce the rules. The rules of the majority of communities are mainly the same: you should respect everyone's privacy, no promotion or spam is allowed, you should be kind and courteous, no hate speech or bullying is allowed [13]. But unlike forum communication, Facebook moderators are not so visible, you rarely see their activity in community as well as you rarely read any posts created by them. We want to concentrate on Facebook community English questions answered with 11.7 thousand members. The group was founded by Hugh Dellar who is a well-known author of the lexical approach in language teaching and the author of Outcomes course. This group is constantly discussing various language phenomena and Hugh Dellar as a moderator and administrator performs an active role in the life of the community that can be illustrated by his recent post:

Hi everyone -

Since Xmas, this group has grown dramatically, which is great. The more, the merrier. However, it also means more work for me as the main moderator.

Just today, I've removed racist comments about the Chinese, a young lad who thought a picture of him posing with a gun might entice you to follow him on Instagram and a Scottish bloke who called me - and I quote - "a fucking know-all wank stain" because I pointed out COMIC was, in fact, an adjective as well as a noun.

I try to ensure the group maintains its focus and quality and that posts are actually questions about English, and that answers are respectful and helpful.

Can I ask all of you to remain vigilant and to report anything you feel is inappropriate. I then get messages, and this helps me deal with things I may otherwise miss.

Cheers. [23]

So, Hugh Dellar sees his function in keeping this community thriving (the more, the merrier, quality of posts, respectful and helpful) and wants to regulate communication in the best way possible (to ensure the group maintains its focus and quality). Moreover, Hugh Dellar is frequently seen in comments and tries to answer all English questions from the point of view of a native speaker that is greatly helpful.

There are not many communities where moderators actively participate and usually, their role is restricted to deleting inappropriate posts and comments. Moreover, cases of spamming or trolling happen from time to time in a community's life but no warnings are issued by moderators, they just block users and delete comments. So, we conclude that although Facebook moderators can be called virtual language identities but they are not so visible in their community. Also, their communicative goal is to enforce the rules and keep order in a community. 
The most widespread type of virtual language identity on the Internet is troll. They act on the Internet with a certain intention to start the conflict and Facebook is not an exception. Troll's main goal is to post rude and provocative comments under users' posts which complicates communication and insults other users $[11$, p. 112]. The examples of trolling can be found in comments to the post of Jennifer Lopez:

\section{Martine Huguet-Latour}

No surgery??? Really? She looks more and more like kris Jenner

Martina Burkovičová Pedersen

Hand washes hand, no surprise here...sick. Hey, money is the source of all evil.

\section{Debbie Underwood}

Not supporting you any longer since you are supporting biden! [27]

This post with Jennifer Lopez on the cover of Elle magazine got 239000 likes and almost 8000 comments. Most comments were favourable, admiring the popular singer but some commentators tried to start an argument as they disagreed with the opinion of the majority. Actually, trolls here avoided profanity and you won't see any swear words but if you analyse deeper in the context you'll see some negativity in their comments (not supporting, looks like Kris Jenner, sick, not supporting you).

Generally, moderators of big communities enforce the rules by deleting offensive comments right away but if we have a closer look at posts of celebrities that gather thousands of likes and comments, we may come across heavy comments that are aimed at starting a heated discussion over the topic. Aguilera's post where she showed her 2 weirdly manicured middle fingers got 7400 comments either praising or disapproving her act. The following comment showing disfavour evoked 475 answers: Laura Markley: I'm disappointed that you would post this. Please set a better example for our youth. Actually, nothing unfavourable can be found in this com- ment and the speaker is extremely polite in her expression (please) but quite negative comments followed up:

Jimmy Sorento@Laura Markley she is what she is Young $\underline{B * * * *}$ with Money

Edgard Miguel Hernandez@Laura Markley girl shut up. she doesn't need to set an example for anyone!! she ain 't their mom

Filipe Roganti@Laura Markley fuck u... Fuck u very very muuu-uuhh-uuh-ch

Michael Crabtree@Laura Markley F\#\#\# off

Jonathan A. Heybroek@Laura Markley 1-5es because 2 middle fingers is the worse thing that has happened, I mean really. It's fucking 2020 I mean jesus.

MichaelWeaver@Laura Markleypls fuck off [22].

These replies contain swear words (shut up, fuck off, fucking $m$ fuck you), imitation of shouting by doubling consonants and vowels (muuu-uuhh-uuh-ch) and even irony (2 middle fingers is the worst thing that has happened). All these verbal characteristics indicate that the users may be classified as Facebook trolls.

Trolls can also have another name such as haters. Actually, that is synonymous phenomena often observed on Facebook and other social networking websites. Trolling as a problem has always been widely discussed and some pieces of advice have been issued to help users deal with it $[1 ; 16 ; 18]$. The main and the most effective way of handling trolls and haters is to ignore them and if it is your post, you can just delete or hide their comments [16]. By doing you, you can start playing the role of virtual identity moderator who often interacts with trolls and haters. So, the role of moderator can be performed by anyone who creates a post and comes across an unfavourable comment that is either deletes or hidden.

The Internet also offers a lot of memes that are used to laugh out trolls and haters and add negative features to their image (Fig. 1).

So, we consider Facebook trolls and haters virtual language identities having their own verbal arsenal that they use while com-

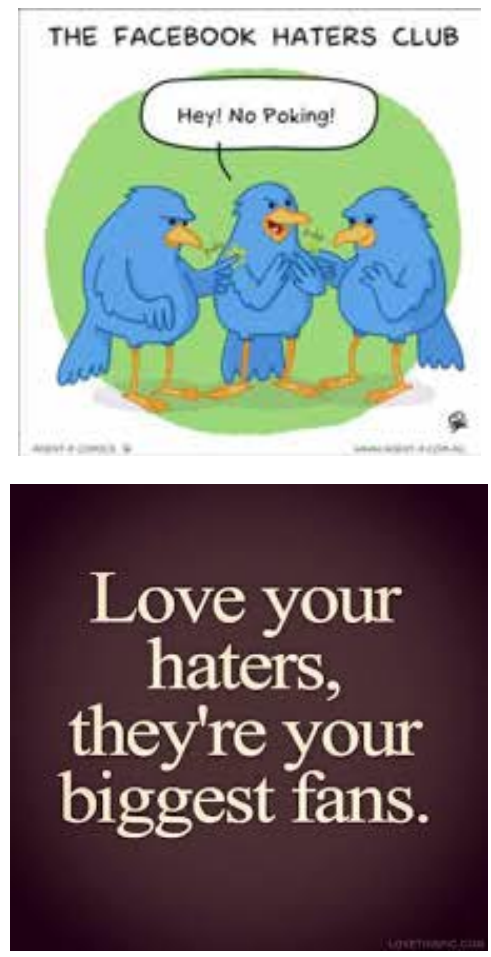

\section{Please do not feed the trolls!}
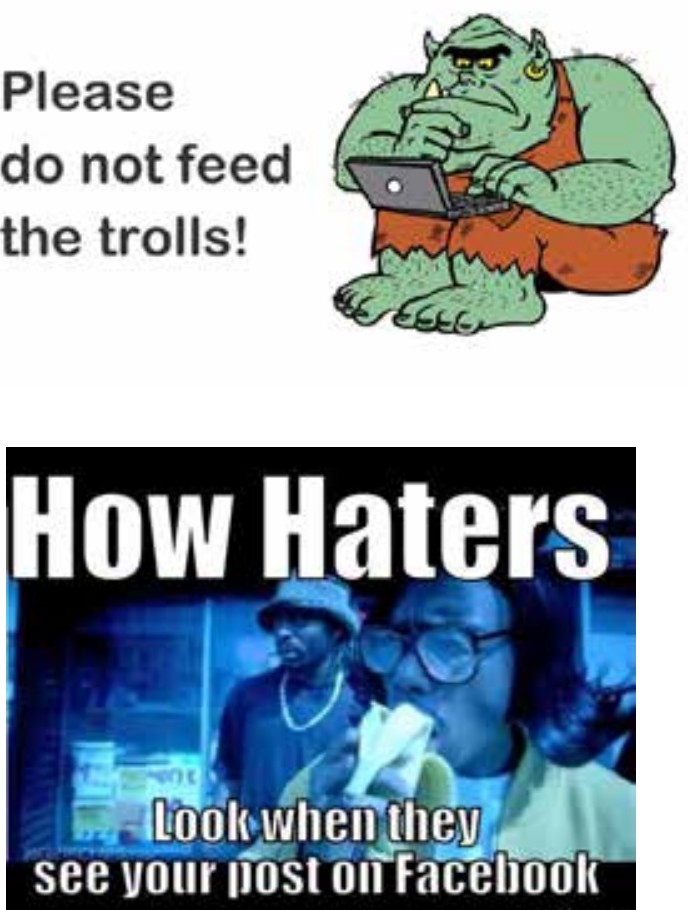

Fig. 1. Internet memes of Facebook haters and trolls [24] 
menting on the posts of other users. Their communicative goal is self-representation through negative comments intended to start a heated discussion and sometimes to insult other users.

The next type of user widespread on Facebook is selfie whose purpose is self-promotion and raising self-esteem. The word selfie is common nowadays and in 2013 was named the word of the year by Oxford Dictionary. Everyone knows selfies who display numerous self-images and photos to gather likes and comments. [14]. The frequency of posting selfies is mostly determined by characteristics of social media audience, namely users with a relatively high number of followers tend to display more selfies [3]. In fact, virtual identity selfie uses mainly a visual component of Facebook for self-representation but without textual or verbal component we cannot consider selfie to be a virtual language identity so it was not the primary focus of our study.

Off-topic speakers and spammers are believed to be conflict communicators as their comments make conversation even more difficult, cumbersome and senseless. Spamming is strictly prohibited by community guidelines. Nevertheless, we can frequently come across spammers in comments to celebrity posts. For example, in the recent publication of Catherine Zeta-Jones where she shows how she practices a new party trick, we can come across the following comment:

YauUmar@Ali Khalid Jumaa I would like to work a successful review about Mrs Zuniga Sheila.I think trading gets easier when you have the right account manager to trade on your behalf I have been working with Mrs Zuniga Sheila for over few weeks and I don't plan on stopping because she has never gave me any reason to doubt her credibility, thank you so much,It will be bad to keep this alone to myself. My passion to trade has grew so big, Mrs Zuniga Sheila have made my world beautiful for earning $\$ 500$ on my little investment of \$5000. Ever since I started investment with Mrs Zuniga Sheila $i$ was always on the good side. she never gamble with me but trade for me, I really do appreciate you and your operators for giving me wonderful earnings.

If fully recommend Her to you all, and to also share this great expe-

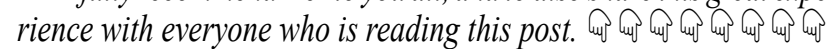

https://www.facebook.com/Zuniga.Sheila.697 [21]

This comment is the reply to Ali Khalid Jumaa's comment No need to do that to get perfection!!? Holding $u$ btw hands is the perfection my adorable Catherine ever!! And it is absolutely obvious that Yah Umar's comment can be considered spam. Moreover, you can come across a similar comment in other replies to this post:

Lynn Hammett Castiglione I would definitely be worried about Michael's shoulder bruises. That has GOT to hurt!

Yau Umar @Lynn Hammett Castiglione Thanks you ma'am I'm so grateful $i$ just received my profits few minutes ago, Thank you so much you kept to you words and promises, now I know the main goal of trading with your platform. Thanks so much fo your help over my trading every day and your good support I'm going to invite my friends and family to trade with you because you have helped me a lot $i$ appreciate your help ma'am $i$ will never stop trading with you ma'am. May God actually reward you for your kindness and being a pure minded person. Thanks so much, I'm so Amazed see my Profits on my wallet w w w w w w

https://www.facebook.com/Zuniga.Sheila.697 [21]

Our observations prove that spammer often communicates with users who comment under celebrities' posts to get more attraction to their posts. Also due to the fact that comments are numerous, they are frequently left unnoticed by moderators.
Off-topic speakers' comments are usually characterised by the use of a meaningless set of letters or symbols:

Salim Jurayev Zo 'o 'o 'o 'o 'o 'o 'o 'rrrrrrrkkkkkkumuи

Aida Martín SHAWN 98798798

Houssine Oukhiera Errich Hhhhhh

Istvan Szasz Sakrsexvdo

Haingotina Irintsoa Naëlle Ddd [26]

These comments to Shakira's post with the presentation of new Video "Girl like me" illustrate characteristic linguistic technique used by off-topic speakers. The attitude of other users to them is rather negative and it can be explained by the fact that their comments complicate communication and irritate other Facebook users. Off-topic speaker's communicative goal is to have fun by sending senseless comments but it also makes discussion cumbersome and difficult for comprehension.

Social networking websites are not only used for fun, a lot of people use it with an informational and educational purpose. This led to the creation of numerous communities where you can find not only approval but also knowledge and even psychological consultation. The data that we have amassed show that virtual language identities as expert, narrator and adviser are present in Facebook commentaries to the posts of such communities. These identities are thought to be highly intellectual, usually having encyclopedic knowledge in different fields as well as having communicative competence $[11$, p. 71$]$. Surely experts communicate mainly in professional communities connected with a certain sphere of interest. The community entitled linguistics is relatively small as it contains only 4000 members but still, you can find something related to your sphere of expertise. Post created by a user to ask for a definition of language arbitraries got some comments. Among them we can easily find the comment of an expert:

\section{Juan Millaruelo}

As David Crystal would say the link between signifier and meaning is not arbitrary if we look at its origin, that is from a historical or ethymological perspective.

It is arbitrary when we descend to the deepest roots.

It is arbitrary because there is a clear dychotomy between code and message, sign and meaning. The structuralist 'eye' studies a system of signs (as well as increasingly complex structures) It deliberately turns its back on the historical evolution of language and defines "a pure theory of language itself". A system of signs and structures.

Things are called the way a society has named them. Meanings are attached to signifiers by social consensus. (arbitrary, but not unfathomable)

But "pure", structuralist linguistics is the study of CODE ITSELF, IN THE ABSTRACT, so the proposition "language is arbitrary' is axiomatic to contemporary theoretical linguistics (including functionalist perspectives)

It is the pivot or keystone of the XXth Century approach to language as an "abstract", and (only) in this sense "arbitrary" system of signs and the different structures they belong to. [28]

This comment clearly illustrates verbal means used by experts in their texts: appeal to authority (as David Crystal would say), repetition (it is arbitrary), well-structured paragraphs, use of professional jargon (axiomatic, dichotomy, structural linguistics etc.). Experts' comments usually have big volume but as their communicative goal is to inform other members of a community and provide information. 
Narrators can also post long comments. The post in the community The Earth Page was created to share emotions evoked in the author during a thunderstorm. It received 157000 likes and almost 2000 comments. Mostly, comments were the following: wow, beautiful, magic, awesome, I like thunderstorms and lightnings. But some speakers shared their fascination by telling the experience they had in every detail:

I've actually seen something similar to this whilst standing on the end of the pier in pensacola beach fl years and years ago... The sky just above me was clear and starry and there must've been a meteor shower because I kept seeing shooting stars then just as I looked out over the horizon Inoticed the big storm cloud just off in the distance then a huge beautiful lightning bolt came straight down out of the cloud and it made the cloud and the ocean so beautifully illuminated... It was absolutely breathtaking and I will never forget that image from my memory [29]

As can be seen from this comment, the speaker relates to his personal experience by telling the story. We call these speakers narrators as their comments remind us a tnarration (story) with background description (the sky was clear and starry), actions in past simple (kept, looked, noticed) and with ending (It was absolutely breathtaking and I will never forget that image from my memory). Narrators usually have a story to tell with the aim of self-representation whereas others usually admire or just like a post.

The anonymity of the Internet promoted the spreading of consultation mode of the Internet. More and more people use it to find answers to their questions. Facebook user is not an exception. Though communicating through their real profiles, users still have a possibility to seek for advice and such communities as Instant Pot Community, Family Lockdown Tips and Ideas, English Questions Answered are aimed at users who want to ask questions, search for some tips and guidelines and post their achievements. Members often post there some pictures and recipes that is illustrated by the following post: My 12 year old said she'd been doing some art to chill between doing school work - in 2 days she produced this using only oil based pencils and watercolour pens! It's amazing but she's still not happy with it [25]. The author here is implicitly asking for advice but gets mostly praise (wow, amazing, awesome, beautiful). But there were other comments that gave really important pieces of advice:

Ves Arslan That's amazing! As an artist myself I would say that she has gotten the elements almost perfect. That iris is spot on. If she wanted to improve it, I'd sav to raise the lower eyelid so it almost touches the iris or covers some of the bottom.

When I was learning to draw eyes, I would look intensely at other people's, look how they move and what they look like. Take as many photos and do lots of smaller sketches to get used to what an eye looks like.

Also, drawing an upper eyelid crease will give you more definition on the eye, and will make it look more realistic

But on the whole, this work is fantastic. What a wonderful natural talent she has [25]

This comment of an adviser has the following verbal characteristics: appeal to a personal experience (as an artist myself, when I was learning to draw eyes), the imperative mood (take photos, do sketches), finishing on a positive note by praising the author's picture (what a wonderful natural talent). All these techniques are peculiar to virtual language identity adviser and make the comment more favourable and create a positive atmosphere within the community.
Conclusions. To conclude, we would like to underline that not every Facebook user can be called a virtual language identity. Virtual language identity is a user who produces text (in our case Facebook commentaries) with the aim of self-representation. We can conclude that only moderator, troll, hater, off-topic speaker, adviser, expert and narrator can be called a virtual language identity as they have their own verbal peculiarities and their mode of behavior. These identities pursue their own communicative goals that are clearly visible in their comments. In the present article, we singled out virtual language identities present in Facebook communication. Further studies may focus on communicative strategies and tactics of these virtual language identities.

\section{References}

1. 4 Tips for Handling Haters on Facebook. Don't let the complaints get the best of you. URL: https://www.inc.com/aj-agrawal/4-tips-for-handling-haters-on-facebook.html (accessed 17.01.2021)

2. Asmus, N.G. Linguistic peculiaries of virtual communicative space (Lingvisticheskie osobennosti virtual'nogo kommunikativnogo prostranstva) diss...kand. filol. nauk: 10.02.19. Chelyabinsk, 2005, 266 p.

3. Barry, C.T., McDougall, K.H., Anderson, A.C., Perkins M.D., Lee-Rowland, L.M., Bender, I., Charles, N.E. 'Check Your Selfie before You Wreck Your Selfie': Personality ratings of Instagram users as a function of self-image posts. Journal of Research in Personality (2019), pp. 1-11.

4. Danah m. boyd, Nicole B. Ellison. Social Network Sites: Definition, History, and Scholarship. Journal of Computer-Mediated Communication, Volume 13, Issue 1, 1 October 2007, P. 210-230.

5. Dressler, A., Dressler, R., Linguistic Identity Positioning in Facebook Posts During Second Language Study Abroad: One Teen's Language Use, Experience, and Awareness. The Canadian Journal of Applied Linguistics, Special Issue: 19, 2 (2016), pp. 22-43.

6. Dziubina, O.I. Structure, semantics and pragmatics of slang neologisms of social networking sites Twitter and Facebook (Struktura, semantyka ta prahmatyka slenhovykh neolohizmiv sotsialnykh merezh Twitter ta Facebook (na materiali anhliiskoi movy)) avtoref. dys. ... kand. filol. nauk : 10.02.04; Lviv. nats. un-t im. Ivana Franka. Lviv, 2016. $18 \mathrm{p}$.

7. Facebook by the Numbers: Stats, Demographics \& Fun Facts. URL: https://www.omnicoreagency.com/facebook-statistics/ (accessed 11.01.2020)

8. Kaptiurova, V.V. Pragmatic principles of message formation on social networking sites amd microblogs (based on English) (Prahmatychni pryntsypy formuvannia povidomlen $u$ sotsialnykh merezhakh $i$ mikroblohakh (na materiali anhliiskoi movy)): dys. ... kand. filol. nauk : 10.02.04 / Kyiv. nats. un-t im. T. Shevchenka. Kyiv, 2014, 235 p.

9. Kompantseva, L.F. Internet communication: cognitive-pragmatic and linguocultural peculiarities (Internet-komunikatsiia: kohnityvno-prahmatychnyi ta linhvokulturolohichnyi aspekty). Dys. ... d. filol. n.: 10.02.02., Kyiv, 2007, 503 p.

10. Lutovinova, O.V. Linguocultural characteristics of virtual discourse (Lingvokul'turologicheskie kharakteristiki virtual'nogo diskursa). Diss ... d. filol. n.: 10.02.19., Volgograd, 2009, 519 p.

11. Nikiforova, Ye.Yu. Profiles of Virtual Language Identities in Forums (Based on English). / Typy virtualnykh movnykh osobystostei u forumnomu prostori (na materiali anhliiskoi movy). Dys. ... kand. filol. n.: 10.02.04 / Kyivskyi natsionalnyi universytet imeni Tarasa Shevchenka. Kyiv. 2018. 250 p.

12. Nikiforova, Ye.Yu. Types of language identities in virtual space (based on Internet forums) (Typy movnykh osobystostei u virtualnomu prostori (na materiali anhlomovnykh Internet-forumiv)). Linhvistyka XXI stolittia: novi doslidzhennia i perspektyvy / NAN Ukrainy, Tsentr naukovykh doslidzhen i vykladannia inozemnykh mov, Kyiv, 2010, p. 194-201.

13. Research in language education. Rules. URL: https://www.facebook. com/groups/902405863258202/about (accessed 15.01.2021) 
14. Science Says There Are Only 4 Types of Facebook Users. URL: https://www.inc.com/jessica-stillman/science-says-there-are-only-4types-of-facebook-us.html (accessed 12.01.2021)

15. Seargeant, P., Tagg, C. The Language of Social Media: Identity and Community on the Internet. PALGRAVE MACMILLAN. 2014. 260p.

16. Six tips to handing haters on Facebook. URL: https://medium.com/@ marketing_75506/6-tips-for-handling-haters-on-facebook-531af9a030fe (accessed 17.01.2021)

17. Social networking service. Wikipedia. URL: https://en.wikipedia.org/ wiki/Social_networking_service (accessed 22.01.2021)

18. Wunderlich, D. How to respond to trolls, haters, and honest feedback on Facebook. URL: https://www.resourceumc.org/en/content/ how-to-respond-when-negativity-hits-your-facebook-page (accesssed 17.01.2021)

19. Zadyraka, K. VIRTUAL IDENTITY: EXAMPLE OF SOCIAL NETWORK FACEBOOK (Virtualna Identychnist: pryklad sotsialnoi merezhi FACEBOOK.) Naukovi zapysky Natsionalnoho universytetu «Ostrozka akademiia». Vypusk 17. 2016. Pp. 309-313.

20. Zheltuhina, M.R., Pavlov, P.V. Social network FACEBOOK as a favorable environment for the formation of the image of the enemy in the mind of the addressee (Social'naya set' FACEBOOK kak blagopriyatnaya sreda dlya formirovaniya obraza vraga v soznanii adresata). Vestnik Centra mezhdunarodnogo obrazovaniya Moskovskogo gosudarstvennogo universiteta. Filologiya. Kul'turologiya. Pedagogika. Metodika, 2015, pp. 76-81.

\section{Illustrative material:}

21. Catherine Zeta-Jones. URL: https://fb.watch/3fKfn4Dfqx/ (accessed 18.01/2021)

22. Christina Aguilera. URL: https://www.facebook.com/christinaaguilera/ posts/10156780722127824 (accessed 16.01.2021)

23. English questions answered. URL: https://www.facebook.com/groups/ englishquestionsanswered/permalink/3048957735390897 (accessed 18.01.2021)

24. Facebook trolls and haters. URL: https://www.google.com/search $? \mathrm{q}=$ Facebook + haters $\&$ source $=1 \mathrm{mns} \& \mathrm{bih}=666 \& \mathrm{biw}=1536 \& \mathrm{hl}=\mathrm{en}$ \&sa $=$ X\&ved=2ahUKEwiu89 WGzLnuAhXWk6QKHfMWCa4Q_ AUoAHoECAEQAA (accessed 17.01.2021)

25. Family lockdown tips and ideas. URL: https://www.facebook.com/ groups/871176893326326/permalink/1173565389754140 (accessed 17.01.2021)

26. GIRL LIKE ME - BEP \& SHAKIRA - THE NEW VIDEO. URL: https://fb.watch/3fJThUsfux/ (accessed 18.01.2021)

27. Jennifer Lopez. URL: https://www.facebook.com/jenniferlopez/ posts/10159010788770768. (accessed 15.01.2021)

28. Linguistics. URL: https://www.facebook.com/groups/1675500809 291896/permalink/1732538913588085 (accessed 19.01.2021)

29. The Earth Page. URL: https://www.facebook.com/thearthpage/ posts/3552145461489179 (accessed 18.01.2021)
Гаврилюк О.О., Нікіфорова Є.Ю. Віртуальні мовні особистості в соціальних мережах (на основі Фейсбуккоментарів)

Анотація. Статтю присвячено лінгвістичному дослідженню віртуальних мовних особистостей, які спілкуються в соціальних мережах, зокрема Фейсбуці. Дослідженні проводилося на основі Фейсбук-коментарів, що дозволило нам створити мовні портрети його користувачів, а також визначити їхні основні комунікативні цілі. Результати дослідження уможливлюють висновки, що не всі користувачі можуть бути віртуальними мовними особистостями, оскільки вони не користуються мовою для створення власного іміджу (йдеться про спостерігачів (lurker, window shopper), любителів селфі (selfie) та спамерів (spammer)). Нами також було визначено та проаналізовано такі типи користувачів Фейсбуку: модератор (moderator), троль або хейтер (troll or hater), флудер (offtopic speaker), експерт (expert), оповідач (narrator) та консультант (adviser). Ці типи віртуальних особистостей $\epsilon$ мовними, оскільки вони продукують текст із метою самопрезентації, вони мають визначені комунікативні цілі та їхні тексти відрізняються набором мовних засобів, які характерні саме для цієї віртуальної мовної особистості. Модератори спілкуються у Фейсбуці з метою дотримання правил, та іноді вони сприяють покращенню комунікації в спільноті. Комунікативною ціллю тролів або хейтерів $є$ ускладнення комунікації та провокування дискусії, також іноді образа інших учасників спільноти. 3 цією метою вони використовують лайливу лексику, яка використовується з метою образити адресата. Флудери також ускладнюють комунікацію, але іншим шляхом. Вони не ображають інших користувачів, проте надсилають беззмістовні коментарі, а також такі, що не стосуються теми дискусії, тим самим перевантажуючи гілку коментарів. Віртуальні мовні особистості «експерт» та «оповідач» спілкуються 3 метою надання інформації, експерт переважно інформативного характеру, тоді як оповідач - переважно емоційного характеру. Коментарі оповідача нагадують наратив із характерними для нього рисами. Консультанти здебільшого спілкуються з іншими користувачами спільноти 3 метою надання допомоги чи поради, їхні коментарі насичені реченнями 3 наказовим способом дії, а також апеляцією до авторитетної особистості або до власного досвіду, що допомагає встановити дружню та довірливу атмосферу. У статті проведено аналіз основних віртуальних мовних особистостей, але не виключено, що інші особистості також там спілкуються.

Ключові слова: соціальна мережа, коментарі Фейсбук, віртуальна мовна особистість, комунікативна ціль, мовні засоби. 